\title{
Participation of Electorates in Non-Voting Activities: A Study of Teok and Mariani Legislative Assembly Constituencies of Assam
}

\author{
Dr. Navajyoti Borah
}

Associate Professor, Department of Political Science, Pandu College, Guwahati, India

Email: njborah.47@gmail.com

\begin{abstract}
Peoples' participation in a democratic process is usually assed by the percentage of voters polled in the elections. But there are certainly other activities through which also a voter can participate in the entire exercise beyond voting. These activities are not generally accounted for by the researchers for studying political participation. In this article, an analysis is being made on the Non Voting activities performed by the voters during the elections. The analysis is based on a field study conducted in two legislative constituencies of Assam.
\end{abstract}

Keywords-Election, Voting, Non-voting, Participation, Political Process.

\section{INTRODUCTION}

Non-Voting participation is one of the areas of peoples' participation in a democratic process. These types of participations are also played a significant role in creating political awareness of the people about ideological orientation and agenda of different political parties on prevailing socio-political and economic issues. Apart from voting there are many other activities through which people /electorates take part in the electoral process, like attending election meetings and rallies, participating in procession or street plays, helping the candidate or the party in door to door canvassing, contribution or collection of money to help candidate or political party, distribution of leaflets or putting up poster, etc. are considered as important. These are activities non-voting activities during the elections. Many people participate in the electoral process through these activities.

\section{OBJECTIVES}

The main objective of this study is to analyze and determine different activities other than voting through which people participate in the electoral process to express their views and opinion on ideologies and agendas political forces on contemporary socio-economic and political issues.

\section{METHODOLOGY}

The study is based on both quantitative and qualitative research; exploratory in nature and consists of various quantitative tools. This is based on primary and secondary data sources. Primary data gathered through a field survey from the respondents who were selected through multistage stratified random sampling. For collecting primary data, the questionnaire method was applied in the field survey.

\section{SAMPLING}

There were 34 Districts in Assam before the 2016 Assembly Election. Jorhat district had been purposively selected for the field survey. Two assembly constituencies namely Mariani and Teok LAC were selected from amongst five Legislative Assembly Constituencies (LAC) of the district. From each of the LAC 4 polling stations were chosen with the help of Stratified Random Sampling (SRS) to give a representation of samples. During the survey-taking average of 25 respondents from each of the selected polling station, a total number of 100 samples were collected

The Activities in which people participate in the democratic electoral process:

To observe the involvement of people in such activities every individual respondent was asked to reply in which of these he or she had participated during the elections. The trend of such participation of people is presented in the table no 1.1

Table: 1.1 Participation of Electorates in Non-Voting Activities

\begin{tabular}{|c|c|c|c|c|}
\hline \multicolumn{2}{|c|}{$\begin{array}{c}\text { Participation of people } \\
\text { in nonvoting activities }\end{array}$} & Male & Female & Total \\
\hline $\begin{array}{c}\text { Attended election } \\
\text { meetings/rallies }\end{array}$ & No & $84.6 \%$ & $81.9 \%$ & $83.4 \%$ \\
\hline & Yes & $15.4 \%$ & $18.1 \%$ & $16.6 \%$ \\
\hline $\begin{array}{c}\text { Participated in } \\
\text { processions/street }\end{array}$ & No & $50.2 \%$ & $34.7 \%$ & $43.1 \%$ \\
\hline
\end{tabular}




\begin{tabular}{|c|c|c|c|c|}
\hline plays & & & & \\
\hline & Yes & $49.8 \%$ & $65.3 \%$ & $56.9 \%$ \\
\hline $\begin{array}{c}\text { Participated in } \\
\text { door to door } \\
\text { canvassing }\end{array}$ & No & $20.7 \%$ & $8.5 \%$ & $15.1 \%$ \\
\hline & Yes & $79.3 \%$ & $91.5 \%$ & $84.9 \%$ \\
\hline $\begin{array}{c}\text { Contributed or } \\
\text { collected money }\end{array}$ & No & $8.8 \%$ & $3.3 \%$ & $6.3 \%$ \\
\hline $\begin{array}{c}\text { Distributed } \\
\text { election leaflets or } \\
\text { put up posters }\end{array}$ & No & $91.2 \%$ & $96.7 \%$ & $93.7 \%$ \\
\hline & Yes & $70.2 \%$ & $87.8 \%$ & $78.3 \%$ \\
\hline
\end{tabular}

Source: Filed Study

From the above table, it can be seen that only 15.4 percent of males and 18 percentage of females, an average of 16.6 percentages of the total respondents attended election meetings or rallies. On the other hand, 49.8 percentage of male 60.3 and percentage of females a total average of 56.9 percentage respondents participated in procession or street plays which were organized by candidates or political parties. The number of respondents told that they had helped a candidate or a political party in the door to door canvassing. 79.3 percent of males and 91.5 percentages of females and 84.9 percentage respondents participated in these activities. A good number of respondents said that they had distributed leaflets and put up a poster during the elections to help some candidates or parties. 70.2 percentage males and 87.8 percentage females out of total 78.3 percentage respondents were involved in this activity. It is very significant to observe that the highest number of 91.2 percentage males and 96.7 percentage females and out of the total 93.7 percentage respondents either collected or contributed money towards some political party in the election. From this, it becomes evident that money has always been playing a crucial role in the elections.

Peoples' Participation in Decision Making Apart from the direct participation of the people in the electoral process through both voting and non-voting activities, many people tried to influence the decision making of the government through different media. People may express their views by writing in a newspaper or by participating in the talk shows/discussions on TV or Radio on certain issues or the decisions taken by the government.

Public meetings are another important medium for the creation of public opinion on certain issues and many people express their views through these meetings. Recently, there has been the increasing popularity of social media as a medium for expressing views and creating public awareness or opinion. In spite of all this, popular mediums of creation of public opinion many people do not or cannot use these to express their views.

\section{Peoples' Participation in Decision Making}

To understand the involvement and interest of the people to express their views through different media an attempt was made during the study. Different Media through which public opinion can be created were placed before the respondents to know their views. For this purpose, the option of "not interested to discuss" was also given to them. The findings of this investigation are presented in Table 1.2

Table: 1.2 Peoples' Participation in Decision Making

\begin{tabular}{|l|c|c|}
\hline Media & Male & Female \\
\hline Newspaper/TV, Radio & $1.3 \%$ & $1.5 \%$ \\
\hline In public meeting & $35.6 \%$ & $18.8 \%$ \\
\hline Not interested to discuss & $53.9 \%$ & $76 \%$ \\
\hline Social media & $9.1 \%$ & $3.7 \%$ \\
\hline Total & $100 \%$ & $100 \%$ \\
\hline
\end{tabular}

Source: Filed Study

The table presented above shows that a very negligible number of respondents express or discuss their views through print, electronic and social media. More than 35.6 percentages of males and 18.8 percentages of females and an average of 28.1 percentages of total respondents participated and expressed their views on the public meetings. A total number of 64.1 percentage respondents were not interested to discuss or express their views in public and social media.

From this result, it is observed that most of the common people are not interested in expressing their views through debates and discussions on certain issues in social media.

\section{Membership of Political Party}

In the previous discussion, it was stated that people could participate in the electoral and political process through a lot of many ways. Some of them are direct and some are indirect. Many people involve themselves in politics by taking party membership or occupying party office to directly influence the party's political decision on different issues. It is a kind of gladiatorial activity in the electoral process. To know the respondent's belongingness of the political party a direct question was put to the respondents during the survey to know their party membership. The results are presented in the table below:

Table: 1.3 Party Membership

\begin{tabular}{|c|c|c|c|c|}
\hline Gender & & Male & Female & Total \\
\hline No & & $29.2 \%$ & $47.6 \%$ & $37.6 \%$ \\
\hline Yes & & $70.8 \%$ & $52.4 \%$ & $62.4 \%$ \\
\hline Total & & $100.0 \%$ & $100.0 \%$ & $100.0 \%$ \\
\hline
\end{tabular}

Source: Filed Study 
The above table shows that 70.8 percentages of males and 52.4 percentages of females said they have party membership. A total number of 62.4 respondents belong to a political party. It indicates that more than 60 percentages of the total respondents have direct involvement with politics.

Some families are traditional supporters of some political parties. Members of such families inherit a party affiliation for generations. It is because of involvement with a party from the beginning of its existence. During the survey, an effort was made to see the involvement of electorates in some political parties from their family perspective. To understand the trend of such support a question was put up before every respondent whether he or she belonged or supported any party to which their parents did not.

Table: 1.4 Family Background of Party Support

\begin{tabular}{|l|c|c|c|}
\hline Gender & Male & Female & Total \\
\hline No & $55.8 \%$ & $72.0 \%$ & $63.2 \%$ \\
\hline $\begin{array}{l}\text { If yes, what is the } \\
\text { reason }\end{array}$ & $44.2 \%$ & $28.0 \%$ & $36.8 \%$ \\
\hline Total & $100.0 \%$ & $100.0 \%$ & $100.0 \%$ \\
\hline \multicolumn{4}{|l}{ Source: Filed Study }
\end{tabular}

The table shows that 63.2 percent of the respondents said that they belonged to the same party to which their parents belonged. On the other hand, 36.8 percentages of the respondents have an affiliation to a party in which their parents were not. It indicates that many people are still traditionally support of some political party their parents or ancestors belonged to.

Table: 1.5 Party Affiliations and Family (Education)

\begin{tabular}{|l|c|c|c|c|c|c|}
\hline $\begin{array}{l}\text { Education } \\
\text { Level }\end{array}$ & Illiterate & Primary & $\begin{array}{l}\text { Metric/ } \\
\text { HS }\end{array}$ & $\begin{array}{l}\text { Degree } \\
\text { and } \\
\text { above }\end{array}$ & $\begin{array}{l}\text { Other } \\
\text { Specialized }\end{array}$ & Total \\
\hline No & $82.4 \%$ & $64.6 \%$ & $63.3 \%$ & $31.7 \%$ & $88.5 \%$ & $63.2 \%$ \\
\hline $\begin{array}{l}\text { If yes, what } \\
\text { is the reason }\end{array}$ & $17.6 \%$ & $35.4 \%$ & $36.7 \%$ & $68.3 \%$ & $11.5 \%$ & $36.8 \%$ \\
\hline Total & $100.0 \%$ & $100.0 \%$ & $100.0 \%$ & $100.0 \%$ & $100.0 \%$ & $\begin{array}{c}100.0 \\
\%\end{array}$ \\
\hline
\end{tabular}

When data were cross-verified taking education as variable as placed in table 1.5 , it is seen that more people with higher-level support or belong to a political party to which their parents did not. It indicates that people with higher education gradually become more conscious and make their individual decision and preferences while choosing a political party in the electoral process.

\section{CONCLUSION}

Democracy in India has been successful to a great extent in the procedural front due to the increasing participation of people in the political process through different forms and mesas. Political participation doesn't merely mean voting in the elections and it is not only a periodic activity by the citizens of a democratic political society. From the above field study analysis it has become evident that not only people participate in different occasional political activities like attending meetings, taking part in processions and rallies, in door to door campaign but many of them continuously attempt to participate in the decision making process of the political authorities through debates, discussions, protest, promoting public opinions through social media or mass media. Some people remain politically active by taking membership of political parties. If voting participation strengthens the procedural democracy, nonvoting participation of people in the political process enhances the qualitative progression of democracy.

\section{REFERENCES}

[1] Hazarika, N. (1978). Role of women in state politics (Assam). The Indian Journal of Political Science, 39(1), 61-78.

[2] Hazarika, S. (2008). Democracy and Leadership: The Gendered Voice in Politics. Sociological Bulletin, 57(3), 353-370

[3] Hussain, M. (1988). High caste to non-caste dominance: the changing pattern of leadership of the congress party in Assam. The Indian Journal of Political Science, 49(3), 402-417

[4] Hussain, M. (1992). Tribal Question in Assam, Economic and Political Weekly, 27(20/21), 1047-1050

[5] Hussain, M. (2003). Governance and Electoral Processes in India's North-East, Economic and Political Weekly, 38(10), 981-990

[6] Goswami, S. (2001). Changing Electoral Trends. Economic and Political Weekly, 36(19), 1584-1586

[7] Goswami, S. (2004). Mixed Verdict, Economic and Political Weekly, 39(51), 5523-5526.

[8] Report on the First Legislative Assembly Election in Assam, 1951-52, Dispur, 1952, 57, 62, 67, 71, 77, 82, $85,91,95,2001,2005,2011 \& 2016$. 